\title{
The Pattern of Distribution of Pneumonic Consolidation in Experimental Peste des petits ruminants Virus (PPRV) and/or Mannheimia Hemolytica Infection in West African Dwarf Goats
}

\author{
Patrón de Distribución de la Consolidación Pneumónica en Infección Experimental con Virus Peste \\ des petits ruminants (PPRV) y/o Mannheimia hemolítica en Cabras Enanas del Oeste Africano
}

\author{
B. O. Emikpe \& S. O. Akpavie
}

EMIKPE B. O. \& AKPAVIE S. O. The pattern of distribution of pneumonic consolidation in experimental Peste des petits ruminants virus (PPRV) and/or Mannheimia hemolytica infection in West African Dwarf Goats. Int. J. Morphol., 28(2):563-568, 2010.

SUMMARY: The study into the pattern of distribution of the lung consolidation associated with common viral and bacterial pneumonia and their co-infection in subsaharan goats is scanty in literatures. Fifty apparently healthy West Africa Dwarf goats (WAD) six months of age were used for the experiment. The animals were divided into groups A, B, and C with 15 goats each while 5 goats served as control. Group A goats infected with 1ml of pure culture (1 X 109 CFU) of Mannheimia haemolytica MH A2, while group B with $1 \mathrm{ml}$ of pure cultured 106.5 TCID50 PPR virus grown in Baby hamster kidney cell lines and group C with $1 \mathrm{ml}$ of PPRV and a week later $1 \mathrm{ml}$ of $\mathrm{MH} \mathrm{A2}$. The degree of consolidation or pneumonia as a percentage of the total lung volume was determined by visual observation, palpation and measurement of the lesion which is estimated as a percentage of each lobe. Student t-test were used to test for significant differences. The right lungs have a higher lung consolidation percentage than the left in all the treatment groups. The accessory lobe was affected in the PPRV group. The MH group has the highest lung consolidation percentage (10.1\%). The PPRV 1-28dpi has the lowest consolidation percentage $(1.06 \%)$. There is significant difference in the consolidation percentage and mortality between $\mathrm{MH}$, PPR+MH, PPRV 28-45 dpi and PPRV 1-28dpi $(\mathrm{P}<0.05)$. This observation further show that the right lung and the anterior lobes were more affected in experimental viral and bacterial respiratory pathogen and their co-infection as the trachea birfucation is first to the right and the distance between the right and the left birfucation was $1.5 \pm 0.35 \mathrm{~cm}$. It is the first study that describes and compare the pattern of distribution and morphometry of pneumonia in experimental PPRV, MH and PPRV+MH infections in goats.

KEY WORDS: Morphometry; Pneumonia; PPRV; Mannheimia hemolytica; Goats.

\section{INTRODUCTION}

Small ruminant production is an important aspect of the livestock economy in developing countries in the humid tropics (Boyazoglu et al., 2005) as more than $80 \%$ of rural families especially women and children keep sheep and goats (Jaitner et al., 2001; Kumar et al., 2003). In Nigeria, 37.4\% and $8.3 \%$ of households keep goats and sheep respectively with an average number per owner being 6.5 (sheep) and 5.2 (goats) (ILCA, 1979).

The goat being an animal that survives most ecological zones is considered to be one of the most important protein producing animals and they provide $30-36 \%$ of the total meat consumption of the Nigerian populace annually (Ademosun, 1985). Nigeria has a small ruminant population of about 34.5 million goats and 22.1 million sheep and of these, $25 \%$ are the West African Dwarf breed that is resident in the humid zone of the country (Larmode, 1980). Due to poor management, inbreeding and inadequate nutrition, these goats are usually predisposed to a range of health problems (RIM, 1992).

The major impediment to their production in most developing countries is the high incidence of infectious diseases with Pneumonia being an important respiratory disorder in sub-Saharan Africa. Of these, Peste des Petit Ruminant Virus (PPRV) and Mannheimia haemolytica are the common causes of viral and bacterial pneumonia in goats in the humid zone of Nigeria. The devastating and endemic nature of PPR infection especially in goats and the usual 
association between PPRV and Mannheimia hemolytica, in the pneumonia of small ruminants (Emikpe, 2009) as observed on the field underscore the need to understand the pattern of lung lesion in these diseases

The patterns of lung lesions in goats and sheep have been previously reported (Ikede, 1977; 1978). In those reports, it was observed that the most prevalent pneumonia in goats was the giant cell type (Ikede, 1977) while that of sheep was the purulent type (Ikede, 1978). The pattern and distribution of lesions in giant cell pneumonia associated with PPRV infection in goats have also been described by Isoun \& Mann (1972). Nduaka \& Ihemelandu (1973) observed lesions in the cranial lobe mainly and the right cranial lobes especially, while the middle and intermediate lobes were affected less and when the caudal lobe was affected, it was only a small anterior portion. This observation was confirmed by Abegunde \& Adu (1977) who also observed pneumonia only on the cranial and the middle lobes of the lungs. Kene (1995), with the use of radiography, similar findings were reported, where he observed that the infiltration of the caudal lobe mainly affect the middle and the ventral part leaving the dorsal part of the lobe almost normal and this distribution was said to be due to gravity. The morphometric studies of the pneumonia associated with experimental Mannheimia hemolytica infection with different serotypes in sheep has been reported (Odugbo et al., 2003; 2004a, b) with very little information in goats.

Inspite of these various studies in small ruminants, the detail sequential morphometric studies in the experimental respiratory infection is scanty in literatures. The study into the pattern and sequential morphometry of the lung lesions associated with the common causes of viral and bacterial pneumonia and their co-infection in goats is expedient for diagnostic importance especially in a developing economy where sophisticated equipments for diagnosis are not available or can not be effectively maintained. The devastating and endemic nature of PPR infection especially in goats and the usual association between PPRV and Mannheimia hemolytica, in the pneumonia of small ruminants as observed in the field created the need to study the pattern of distribution and morphometry of lung consolidation experimental PPRV and/ or Mannheimia hemolytica infection in West African Dwarf goats very crucial hence this study.

\section{MATERIAL AND METHOD}

Study Location.The small ruminant pens of the Veterinary Pathology Department, in the experimental animal unit of the Faculty of Veterinary Medicine, University of Ibadan were used for this study.

Experimental Animals. Fifty apparently normal West Africa Dwarf goats (WAD) six months of age were used for the experiment. The animals were divided into four well partitioned pens. Group A, B and C had 15 goats each while 5 goats served as control. They were conditioned for 14 days before the intervention and vital signs (rectal temperature, pulse and respiratory rates) were monitored daily to observe whether they remained afebrile and free of any clinical signs of diseases. Wheat bran and water were provided ad libitum daily. The nasal swabs of the animals were negative for Mannheimia haemolytica by cultural isolation prior to inoculation. The animals were also confirmed seronegative by Agar gel precipitation technique for antibody to peste des petit ruminants virus (PPRV) prior to inoculation.

Challenge Infection. Fifteen goats from each group were infected intratracheally according to the method described by Ames et al., (1985) while five uninfected control goats were inoculated intratracheally with $1 \mathrm{ml}$ of sterile brain

Table I. showing the treatment groups and infective agent used.

\begin{tabular}{|c|c|c|}
\hline Treatment groups & Numbers of animals & Infection \\
\hline $\mathrm{MH}$ & 15 & $\begin{array}{l}1 \mathrm{ml} \text { of pure culture }\left(1 \times 10^{9} \mathrm{CFU}\right) \text { of a } 4 \text { hour log phase culture of } \\
\text { Mannheimia haemolytica } \mathrm{A} 2\end{array}$ \\
\hline PPRV & 15 & $\begin{array}{l}\text { 1ml of pure cultured PPR virus grown in Baby hamster kidney cell } \\
\text { lines (BHK) using a titre of } 10^{6.5} \text { TCID50. }\end{array}$ \\
\hline $\mathrm{PPRV}+\mathrm{MH}$ & 15 & $\begin{array}{l}1 \mathrm{ml} \text { PPRV and a week later } 1 \mathrm{ml} \text { of pure culture }\left(10^{9} \mathrm{CFU}\right) \text { of } \\
\text { Mannheimia haemolytica } \mathrm{A} 2 \mathrm{MH}\end{array}$ \\
\hline Control & 5 & None \\
\hline
\end{tabular}


infusion broth. The infection was carried out as enumerated below. The Mannheimia haemolytica A2 was supplied by Professor A.I. Adetosoye of the Department of Veterinary Microbiology and Parasitology of University of Ibadan. The number of CFU per $\mathrm{ml}$ of inoculum was determined by pour plate methods (Quinn et al., 1994).

Pathology. The animals that died were necropsied but two animals were euthanised at predetermined days. Adequate measures were taken to minimize pain or discomfort. The experiment was carried out in accordance with the Guidelines laid down by the National Institute of Health (NIH) in the USA regarding the care and use of animals for experimental procedures or with the European Communities Council Directive of 24 November 1986 (86/ $609 /$ EEC) and in accordance with local laws and regulations.

For the lung pathology, the degree of consolidation or pneumonia as a percentage of the total lung volume, was estimated as described by Jericho \& Langford (1982) and Odugbo et al., (2004a). The extent of pneumonia was determined by visual observation, palpation and measurement of the lesion which is manually plotted onto a lung diagram and then estimated as a percentage of each lobe.

Statistical Analysis. Student t-test were used to test for significant differences in the side of lung affected (Petrie \& Watson, 1999).

\section{RESULTS}

Table II, showed that the right lungs in all the treatment groups have a higher lung consolidation percentage than the left in all the groups. The accessory lobe was affected only in the PPRV group. The MH group has the highest lung consolidation percentage (10.1\%). The PPRV 1-28dpi has the lowest consolidation percentage (1.06\%). The PPRV 28 - 45 dpi (6.83) is similar in the consolidation \% with experimental PPRV+MH (7.01). There is significant difference in the consolidation percentage and mortality between $\mathrm{MH}$, PPR+MH, PPRV 28 - 45 dpi and PPRV 1-28dpi $(\mathrm{p}<0.05)$.

Table II. Pattern of distribution and morphometry of lung consolidation experimental PPRV and/or Mannheimia hemolytica infection in West African Dwarf goats.

\begin{tabular}{|c|c|c|c|c|}
\hline LOBES OF THE LUNG & $\begin{array}{l}\text { MH } \\
\text { (a) (15 goats })\end{array}$ & $\begin{array}{l}\text { PPRV } \\
\text { (b) (10 goats) } \\
1-28 \text { dpi }\end{array}$ & $\begin{array}{l}\text { PPRV } \\
\text { (c) ( } 5 \text { goats) } \\
28-45 \text { dpi }\end{array}$ & $\begin{array}{l}\text { PPRV+MH } \\
\text { (d) (15 goats) }\end{array}$ \\
\hline Left cranial & 1.67 & 0.03 & 0.92 & 1.16 \\
\hline Left caudal & 2.12 & 0 & 1.71 & 0.64 \\
\hline Total & 3.78 & 0.03 & 3.63 & 1.8 \\
\hline Right cranial & 2.53 & 0.76 & 2.43 & 2.9 \\
\hline Right middle & 1.83 & 0.16 & 1.13 & 1.24 \\
\hline Right caudal & 1.89 & 0 & 0.23 & 1.05 \\
\hline Total & 6.224 & 0.92 & 3.8 & 5.21 \\
\hline Accessory & - & 0.11 & 0.41 & - \\
\hline Total Lung consolidation $\%$ & 10.1 & 1.06 & 6.83 & 7.01 \\
\hline Mortality rate & 20 & 0 & 80 & 33.3 \\
\hline
\end{tabular}

\section{DISCUSSION}

The detailed distribution of lung lesions in single and concurrent virus and bacterium infection and the use of lung consolidation score in explaining the pathogenesis of such diseases and their interactions is scanty in literatures except 
for the report of Odugbo et al. (2004b), who used the method in showing the variation in the pathogenicity of different serovars of MH isolated from sheep in Nigeria. This study therefore is the first to use lung scoring method to evaluate and compare the pattern of distribution and morphometry of pneumonia in experimental PPRV, $\mathrm{MH}$ and PPRV+MH infections in goats.

In this investigations, the right lungs in all the treatment groups have a higher lung consolidation percentage than the left with significant difference in PPRV $+\mathrm{MH}$ and $\mathrm{MH}$ group while the accessory lobe was affected only in the PPRV group. These findings are similar to what had been observed naturally especially in natural PPRV and complicated PPRV infection in goat and sheep (Isoun \& Mann; Nduaka \& Ihemelandu; Abegunde \& Adu; Ikede, 1977; Kene). The fact that the lesions were commonly observed in the anterior lobes of both lungs may be associated with the fact that virus titres were higher in anterior lobes than the caudal lobes (Davies et al., 1982). The anterior lobar distribution may be due to the increase in particle deposition which has been attributed to shorter and more abrupt branching airways. The gravitational influence has also been reported to impede clearance at this region and possibly lead to pooling or reflux of secretions. The smaller size of ventral airspaces and their preponderance to collapse or blockage may also be associated to the vulnerability of this region (Thomson, 1983).

That the MH group has the highest lung consolidation percentage $(10.1 \%)$ while the PPRV infection between 1-28dpi has the lowest consolidation percentage $(1.06 \%)$ showed how fulminating MH infection can be in nature while the viral pneumonia can be characterised by low consolidation of the lung tissue. This may be associated with type of pneumonia associated with the agents as bacterial agents tend to cause bronchopneumonia with marked and higher consolidation than viral induced interstitial pneumonias. The effect on the lung may not truly represent the pathogenicity and fatality of PPRV infection in goats as PPRV do affect the respiratory and the digestive system and the mortality associated with PPRV has been associated more with the effect on the digestive system than respiratory system especially when enteritis ensues with resultant projectile diarrhoea and death which are usually due to marked dehydration and electrolyte imbalance.

The pulmonary consolidation observed in PPRV 28 - 45 dpi (6.83) (after confirmed bacterial involvement) was similar to that of experimental PPRV+MH (7.01), hence there is significant difference in the consolidation $\%$ between MH, PPR+MH, PPRV 28 - 45 dpi and PPRV 128dpi.
This observation further confirms the enhancement of pulmonary lesion by the bacterium and the fact that $\mathrm{MH}$ contributes to the fatality of PPRV via the damage to respiratory system especially the lung. This enhancement may be associated with the immunosuppressive effect of the virus which reduces the efficiency of the alveolar macrophages to clear bacteria in the lower respiratory tract hence the bacterial adhesion to epithelial cell surfaces which further play a major role in the bacterial colonization and the resultant disease (El Ahmer et al.., 1996, 1999).

The right lung could be more affected in West African Dwarf goat as the trachea birfucation is first to the right and the distance between the right and the left birfucation was $1.5 \pm 0.35 \mathrm{~cm}$. In this study the caudal lobe was affected when there was bacterial involvement in the viral respiratory infection.

In the $\mathrm{MH}$ group however, the percentage consolidation of $10.1 \%$ is similar to the $12 \%$ recorded in cattle by Thompson et al., but not the $66.3 \%$ reported for sheep in Nigeria (Odugbo et al., 2004a) and 22\% for goat in Malaysia (Zamri-saad et al.,1989). This high lesion score reported for sheep in Nigeria by Odugbo et al. (2004a) may be associated with the challenge dose used which was about seven times that used in this experiment. The lung lesions were more severe in the right lung than the left while there seems to be predilection for the cranial lobes. There is no sex predisposition in the spread and pattern of the lung lesions in this study. In the co- infection $\mathrm{PPRV}+\mathrm{MH}$ group, the average lung consolidation was $7.01 \%$ with the right lung more affected $(5.21 \%)$ than the left $(1.8 \%)$ while there seems to be predilection for the cranial lobes and middle lobes of both lungs. The mortality pattern is very much related to the lung consolidation pattern which buttress the fact that pneumonia is one of the leading cause of mortality in small ruminants (Ikede, 1977; 1978).

It is then clear that pneumonia disease assessment using scoring methods can be an important diagnostic tool for practitioners and researchers (Sharma \& Woldehiwet, 1990) and can be used for evaluating factors associated with an increase in incidence and severity of lung lesions. It can also be useful for respiratory disease surveillance and evaluation of the economic impact of respiratory diseases (Maes et al., 2001). This assessment and periodic surveillance with the use of scoring system is important in a developing economy with less sophisticated equipment for diagnosis as pneumonic conditions is still a significant problem of the livestock industry. The economic losses are primarily due to the reduction of daily weight gain and feed efficiency of the infected animals (Hill et al., 1992). 
Moreover, the instauration of secondary infections in these animals and the increase in the treatment costs are also considered as additional economic losses (Kyriakis et al., 2001).
ACKNOWLEDGMENTS. We are grateful to University of Ibadan/The John D. and Catherine T. MacArthur foundation grants for staff development given to the first author for the completion of his $\mathrm{PhD}$ programme.

EMIKPE B. O. \& AKPAVIE S. O. Patrón de distribución de la consolidación pneumónica en infección experimental con virus Peste des petits ruminants (PPRV) y/o Mannheimia hemolítica en cabras enanas del Oeste Africano. Int. J. Morphol., 28(2):563-568, 2010.

RESUMEN: El estudio sobre el patrón de distribución de la consolidación pulmonar asociada con neumonía virales y bacterianas comunes y sus co-infección en cabras Subsaharianas, es escasa en la literatura. Cincuenta cabras enanas de África occidental (WAD) aparentemente sanas de seis meses de edad fueron utilizados para el experimento. Los animales se dividieron en grupos A, B y C con 15 cabras cada uno mientras que el 5 cabras sirvió como control. Grupo A cabras infectadas con 1 ml de cultivo puro (1 X 109 UFC) de Mannheimia haemolytica MH A2, mientras que el grupo B con $1 \mathrm{ml}$ de cultivo puro 10 6,5 DICT50 PPR cultivado en líneas celulares de riñón de crías de hámsters y el grupo C con $1 \mathrm{ml}$ de PPRV y un semana después de $1 \mathrm{ml}$ de $\mathrm{MH}$ A2. El grado de consolidación o neumonía como porcentaje del volumen pulmonar total se determinó por observación visual, palpación y la medición de la lesión que se estima como un porcentaje de cada lóbulo. El test t de Student se utilizaron para probar las diferencias significativas. El pulmón derecho tiene un porcentaje de consolidación pulmonar superior a izquierdo en todos los grupos de tratamiento. El lóbulo accesorio se vio afectado en el grupo de PPRV. El grupo MH tiene el porcentaje más alto de consolidación pulmonar (10,1\%). El PPRV 1-28dpi tiene el menor porcentaje de consolidación (1,06\%). No hay diferencia significativa en el porcentaje de consolidación y la mortalidad entre MH, MH + PPR, PPRV 28-45 dpi y PPRV 1-28dpi $(\mathrm{P}<0,05)$. Esta observación muestra además que el pulmón derecho y los lóbulos anteriores se vieron más afectados en infecciones respiratorias patógenas experimentales con agentes virales y bacterianos y su co-infección como la bifurcación traqueal es primero a la derecha y la distancia entre la derecha y la bifurcación izquierda fue de 1,5 $\pm 0,35 \mathrm{~cm}$. Es el primer estudio que describe y compara el patrón de distribución y la morfometría de las neumonías en PPRV experimentales, MH y MH + PPRV infecciones en el ganado caprino.

PALABRAS CLAVE: Morfometría; Pneumonía; PPRV; Mannheimia hemolytica; Cabras.

\section{REFERENCES}

Abegunde, A. \& Adu, F. D. Excretion of the virus of peste des petits ruminants by goats. Bull. Anim. Hlth. Prod. Afr., 25:207-311, 1977.

Ademosun, A. A. Contributions of research to small ruminants production in Nigeria. In: Adu, I. F.; Osinowo, O. A.; Taiwo, B. B. A. \& Alhassan, W. S. (Eds). Small ruminant production in Nigeria. Proceedings of National Conference on Small Ruminant Production held in Zaria, Nigeria, 6-10 October 1985. Shika, NAPRI (National Animal Production Research Institute), 1985.

Ames, T. R.; Markham, R. J.; Opuda-Asibo, J.; Leininger, J. R. \& Maheswaran, S. K. Pulmonary response to intratracheal challenge with Pasteurella haemolytica and Pasteurella multocida. Can. J. Comp. Med., 49(4):395400, 1985.

Boyazoglu, J.; Hatziminaoglou, I. \& Morand-Fehr P. The role of the goat in society: Past, present and perspectives for the future. Small Rumin. Res., 60:13-23, 2005.

Davies, D. H.; Herceg, M. \& Thurley, D. C. Experimental infection of lambs with an adenovirus followed by Pasteurella hemolytica. Vet. Microbiol., 7: 369-81, 1982.
Elahmer, O. R.; Raza, M. W.; Ogilvie, M. M.; Blackwell, C. C.; Weir, D. M. \& Elton, R. A. The effect of respiratory virus infection on expression of cell surface antigens associated with binding of potentially pathogenic bacteria. Adv. Exp. Med. Biol., 408:169-77, 1996.

Elahmer, O. R.; Raza, M. W.; Ogilvie, M. M.; Weir, D. M. \& Blackwell, C. C. Binding of bacteria to HEp-2 cells infected with influenza A virus. FEMS Immunol. Med. Microbiol., 23:331-41, 1999.

Emikpe, B. O. The role of Mannheimia hemolytica $(\mathrm{MH})$ in the pathology of experimental Peste Des Petits Ruminants Virus (PPRV) infection in West African Dwarf goats. PhD thesis, University of Ibadan, Nigeria, 2009. pp. 289.

Hill, M. A.; Scheidt, A. B.; Teclaw, R. F.; Clark, L. K.; Knox, K. E. \& Jordan, M. Association between growth indicators and volume of lesions in lungs at slaughter. Am. J. Vet. Res., 53:2221-3, 1992.

Ikede, B. O. The Pattern of respiratory lesions in goats and sheep in Nigeria, Part I- lesions in goats. Bull. Anim. Health Prod. Afr., 16:49-59, 1977. 
Ikede, B. O. The Pattern of respiratory lesions of goats and sheep in Nigeria, Part II - lesions in sheep. Bull. Anim. Health Prod. Afr., 26(2):172-85, 1978.

International Livestock Centre for Africa (ILCA). Small Ruminant Production in the Humid Tropics. Systems study No. 3. Addis Ababa, Ethiopia, ILCA, 1979. p.4.

Isoun, T. T. \& Mann, E. D. Stomatitis and pneumoenteritis complex of sheep in Nigeria. Bull. Epizoot. Dis. Afr., 20:21-30, 1972.

Jaitner, J.; Sowe, J.; Secka-Njie, E. \& Dempfle, L. Ownership pattern and management practices of small ruminants in the Gambia - implications for a breeding programme. Small Rum. Res., 40:101-8, 2001.

Jericho, K.W. \& Langford, E. V. Aerosol vaccination of calves with Pasteurella haemolytica against experimental respiratory disease. Can. J. Comp. Med., 46:28792, 1982.

Kene R. O. C. Radiographic changes in the lower respiratory tracts of West African dwarf goats suffering from peste des petits ruminants. Trop. Vet., 5-13, 1995.

Kumar, S.; Vihan, V. S. \& Deoghare, P. R. Economic implication of diseases in goats in India with references to implementation of a health plan calendar. Small Rum. Res., 47:159-64, 2003.

Kyriakis, S. C., C. Alexopoulos, J. Vlemmas, K. Sarris, S. Lekkas, M. Koutsoviti- Papadopoulou, and K. Saoulidis. Field study on the efficacy of two different vaccination schedules with HYORESP in a Mycoplasma hyopneumoniae-infected commercial pig unit. J. Vet. Med. B Infect. Dis. Vet. Public Health, 48:675-84, 2001.

Lamorde, A. G. Welcome address. Ibadan, Proceedings of the 1st International Workshop on PPR, 1980. pp.1-2.

Maes, D. G.; Deluyker, H.; Verdonck, M.; de Kruif, A.; Ducatelle, R.; Castryck, F.; Miry, M. \& Vrijens, B. Noninfectious factors associated with macroscopic and microscopic lung lesion in slaughter pigs from farrowto-finish herds. Vet. Rec., 148:41-6, 2001.

Nduaka, O. \& Ihemelandu, E. C. Observation on pneumonia - enteritis complex in dwarf goats in Eastern States of Nigeria - preliminary report. Bull. Epizoot. Dis. Afr., 21:89-98, 1973.
Odugbo, M. O.; Odama, L. E.; Umoh, J. U. \& Makinde A. A. Serotypes of Pasteurella haemolytica from pneumonic lungs of sheep in Northern Nigeria. Small Rum. Res., 48:239-43, 2003.

Odugbo, M. O.; Odama, L. E.; Umoh, J. U. \& Lombin, L. H. The comparative pathogenicity of strains of eight serovars and untypeable strains of Mannheimia haemolytica in experimental pneumonia of sheep. Vet. Res. 35:661-9, 2004a.

Odugbo, M. O.; Okpara, J. O.; Abechi, S. A. \& Kumbish, P. R. An outbreak of pneumonic pasteurellosis in sheep due to Mannheimia (Pasteurella) haemolytica serotype 7. Vet. J., 167:214-5, 2004 b.

Petrie, A. \& Watson, P. Statistics for Veterinary and Animal Science. Oxford, Blackwell Science Ltd., 1999.

Quinn, P. J.; Carter, M. E.; Markey, B. \& Carter, G.R. Bacterial pathogens: microscopy, culture and identification. In: Clinical Veterinary Microbiology. London, Wolfe Publishing, 1994. pp. 21-60.

RIM, Nigerian National Livestock Resource Survey. Report by Resource Inventory and Management Limited (RIM) to FDL\& PCS, Abuja, Nigeria. 1992.

Sharma, R. \& Woldehiwet, Z. Increased susceptibility to Pasteurella haemolytica in lambs infected with bovine respiratory Syncytial virus. J. Comp. Pathol., 103:411$20,1990$.

Thomson R. G. The pathogenesis and lesions of pneumonia in cattle. Food Animal Practice Eds. New Jersey, Veterinary Learning Systems Trenton, 1993. pp:79-86.

Zamri-Saad, M.; Sharif, H. \& Basri, K. Microbiological and pathological evaluation of vaccination against naturally occurring caprine pasteurellosis. Vet. Rec., 124:171-2, 1989.

Correspondence to:

Dr. B. O. Emikpe

Department of Veterinary Pathology,

University of Ibadan

NIGERIA

Email: banabis2001@yahoo.com bo.emikpe@mail ui.edu.ng

Received: 03-11-2009

Accepted: 14-07-2009 